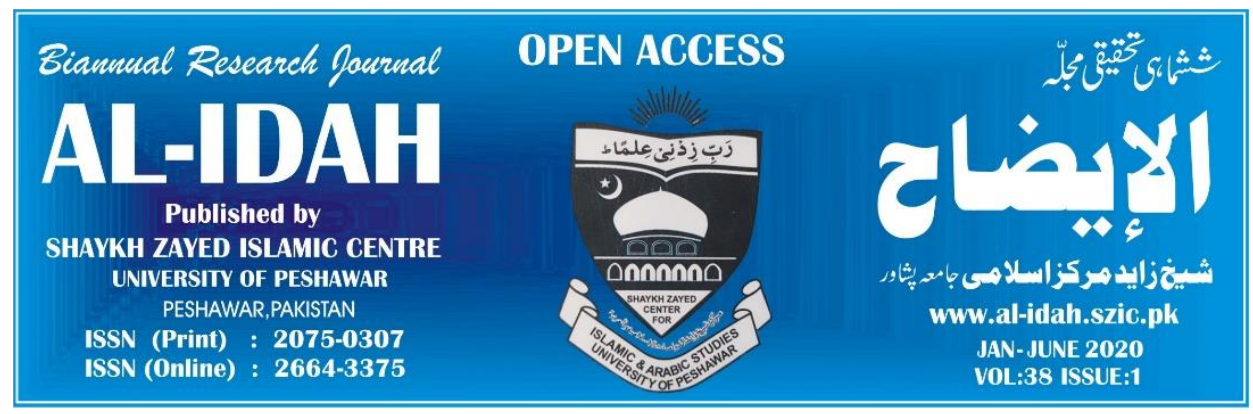

\title{
Dating of Isnād and Western Scholarship
}

\author{
Alam Khan \\ Assistant Professor, Department of Hadith, Faculty of Theology \\ University of Gumushane -Turkey.
}

\section{Article DOI: https://doi.org/10.37556/al-idah.038.01.0620}

\begin{abstract}
Isnād system is the distinction of Muslim Ummah which is praised by its critics too because it is a source of access to the origin of every information. Muslim scholarship called it religion and did not accept hadith without Isnäd. Especially after the first Civil War -when the fabrication of hadith appeared in Muslim society- the Muhaddithūn thoroughly scrutinised the traditions and transmitters to differentiate the authentic Ahādith from the weak and fabricated.

On the other hand, when Western scholarship started source criticism, they considered Isnād system as a source of dating Hadith. Therefore, most of their theories and conclusions about the authenticity of Hadith based on it. They put in question the Isnād system as Prophetic Hadith and tried to find out its dating in their studies. Some of them claimed that Muhaddithün fabricated it in the second century and onwards while the others argued that it was used after the first half of the first century. However, both considered it later addition to the hadith literature. This study deals with the theories of Western scholars about the dating of Isnād and its comparison with historical facts.

Keywords: $\quad$ Hadith, Isnād, Orientalism, History of Islam, Transmitters.
\end{abstract}

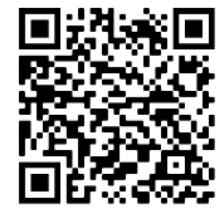

Scan for Download

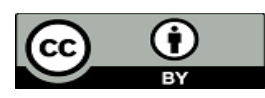




\section{Introduction:}

Islam is one of those subjects that is firmly studied in the western world. They established numeral institutes, which encourage and facilitate the researchers for the study of Islam and its related subjects. The dating of Islamic studies in the West might not go back earlier than the $12^{\text {th }}$ century because the first Latin translation of the Holy Qur'ān was appeared in (537/1143), which was ascribed to Peter the Venerable (d. 550/1156) ${ }^{(1)}$.

In the beginning, Western scholars focused on oriental languages, cultures, traditions and scientific heritage. They edited and published a bulk of classicalbooks in Arabic literature, Sira, Ansāb, Ahādìth and exegesis of the Qur'ān such as al-Kāmil, Futūh al-Buldān, Kitāb al-Ansāb, Sira Ibn Hishām, al-Tabaqātu'lKübrā li'l-Wāqidī, Tārīkh al-Tabarī, al-Mu ‘jam al-Mufahras li alfāz al-Hadìth and many others, which is considered a praiseworthy addition of Western scholarship to Islamic library ${ }^{(2)}$.

The interests and objectives of Western scholars changed with the passage of time towards the study of Islam. They challenged the authenticity of Islamic history and intended to rewrite the history of the early ages of Islam. However, they believed that the Prophetic Ahādith could be sufficient source in this regard. Therefore, they focused on the study of Ahādith for collecting historical information. Hence, they started source criticism instead of compiling Islamic history, and developed new methods as well as theories about the provenance and authorship of the Prophetic Ahädith.

Ignaz Goldziher (d. 1339/1921) was considered the first western scholar who systematically studied the Ahāaith and challenged its authenticity in his renowned book Muslim Studies. He was followed by a German-Britain scholar Joseph Schacht (d. 1388/1969) in developing sceptical theories about the second source of Islamic law and published The Origins of Muhammadan Jurisprudence as a conclusion of his critical research. The main difference between the two studies was that the former was related to the Mutūn al-Hadìth, while the later is about Isnād system of Hadith ${ }^{(3)}$.

In the same era, Aloys Sprenger (d. 1310/1893), J. Horovitz (d. 1349/1931), Leone Caetani (d. 1353/1935), James Robson (d. 1401/1981) and others criticised the ahādith and questioned the Isnād system. Muslim theologians such as $M$. Sibā'̄ (d. 1383/1964), M. M. Azamī (d. 1438/2017), and Fuat Sezgin (d. 1439/2018) assessed their theories and advocated the Prophetic ahädith in their works. However, at the end of the $20^{\text {th }}$ century, G. H. A Juynboll (d. 1431/2010) developed those sceptical theories on new methods and supported the thesis of the earlier western scholars with new arguments ${ }^{(4)}$.

The follow-up of those western critical studies revealed that Isnād were introduced and added to Hadith very late. However, they are not on one page about the dating of Isnäd, which would be discussed in the following lines.

\section{The Dating of Isnād and Western Scholars:}

The subject of Isnād is not unfamiliar for Muslim theologians and Western scholars because both scholarships linked the authenticity and dating of Hadith 
with it. Muhaddīthīn considered it as a tool of access to the grad of Hadìth, while the Western scholars supposed it as a source of dating Hadith. Moreover, Western scholarship believed that Isnād system was not used in the early ages of Islam as Muhaddithīn claimed. The theories of Western scholars about the dating of Isnād could be divided into two groups as follow.

\subsection{Use of Isnād Later Than First Century:}

A group of Orientalists believe that using Isnād was not in practice during firstcentury A.H, and supported their thesis with historical traditions. A thorough review of Western scholars works revealed that the Italian orientalist Leone Caetani was the first one who put in question the authenticity of Isnād as well as its provenance in the first century A. H. He argued that Urwa b. al-Zubaīr (d. 94/713) was the oldest collector of the Prophetic Ahädith. However, he neither used Isnād nor mentioned his source except the Holy Qur'ān as al-Tabarī (d. 310/923) narrated from him. M. M. Azamī discussed Leone Caetani's theory and elucidated that Urwa b. al-Zubaìr was in the reign of Abdulmālik (80-70), which indicate to the conclusion of Caetani that Isnād was not familiar among the Muslims at least until (70) after Hijra. Furthermore, Leone Caetani claimed that Muhaddithūn fabricated and added Isnād to the cluster of ahädìth in the period between Urwa bn al-Zubaīr and Ibn Ishāq (d. 150/767), which could be supposed the end of the second century, and perhaps also in the third ${ }^{(5)}$.

Aloys Sprenger followed the same method and concluded that the letters of Urwa b. al-Zubaīr was free of Isnād, and considered his Isnād in some sources is the later ascription to him. Joseph Schacht linked the dating of Isnād with the dating of hadith criticism and considered it later addition as well. He countered the wellknown narration of Muhammad b. Sirīn (d. 110/729) regarding the questioning of Muhaddithūn about the source of a narrator ${ }^{(6)}$, and concluded that it is a fabricated narration which ascribed to Ibn Sirin after his death because it is included information related the Civil War which is occurred in (126/744), and it is not possible that he could talk about what would be occurred after his death. Consequently, Schacht challenged the authenticity of this tradition as well as denied the origin of Isnād before the second century ${ }^{(7)}$.

\subsection{Use of Isnād at the End of the First Century:}

The prominent Western scholars such as J. Horovitz, Ignaz Goldziher, and Robson believe that Isnād used in the first century A. H. J. Horovitz countered the theory of those western scholars who criticised the Isnād of Urwa b. al-Zubaīr in his letters to Abdulmālik b. Marwān, and claimed that these letters are free of Isnād as al-Tabarī quoted. J. Horovitz argued that al-Tabari was not the single source for the letters of Urwa. There were other earlier sources like Ibn Shihāb alZuhrī (d. 124/742) who narrated it on his chains. However, these critics did not investigate all sources of Urwa b. al-Zubaīr's letters in the classical canonical books and predicated their theories on al-Tabarī, which is insufficient for the final scientific conclusion ${ }^{(8)}$.

Robson followed the same method in the dating of Isnād in the first century and supported his thesis that many of the Companions were dead in the first half of 
the first century, and the Successors who had not seen the Prophet would be narrating Ahädith of him. Naturally, it is possible that students might have asked them about their sources, and they referred to them. Additionally, he illustrated that we know that Ibn Ishāq, in the first half of the second century, could give much of his information without an Isnād, and much of the remainder without a perfect one. His predecessor would almost certainly be even less particular than he in documenting their information. However, we are not justified in assuming that Isnäd is a development of al-Zuhrì's period and was unknown to Urwa bn alZubaīr ${ }^{\text {(?) }}$.

G. H. A Juynboll also studied the same subject and developed the theories of early scholars regarding the dating of Isnād in his works, and argued that Isnād was not used among the Muslims in the early ages of the first century. Juynboll supported the thesis of Joseph Schacht about the criticism of hadith with new arguments and concluded that it is started after the second quarter of the second century because he belive that Shu 'ba b. al-Hajjajj (d. 160/777) was the first critic of hadīth transmitters who later followed by Yahya b. Saìd al-Qatān (d. 198/814). However, he did not agree with Joseph Schacht's conclusion about the narration of Ibn Sirin. He agreed with J. Robson that it is an authentic narration and Ibn Sirin talked about the Civil War which occurred between Abdullāh b. al-Zubaìr (d. 72/692) and Abdulmālik b. Marwān. Hence, he credited the conclusion of J. Horovitz and others that Isnād used in the second half of the first century ${ }^{(10)}$.

\section{Appraisal of Orientalists Theories about the Dating of Isnād:}

Muhaddīthūn considered Isnād is a part of religion as Abdullāh b. al-Mübārak (d. 181/797) stated: "Isnād is part of the religion. If it were not for the Isnād, anyone would say whatever he wishes to say". Therefore, Muhaddithün paid sufficient attention to its uses ${ }^{(11)}$.

On the other hand, Western scholarship also focused on Isnād and considered it a source of access to the dating of hadith. Joseph Schacht introduced the Commonlink theory to find out when a hadith came into being or circulated in the hadith's centres. G. H. A Juybnboll developed Schacht's theory for the same purpose and tried to find out the Partial, Seeming and Real Common-link through the studying of Isnād system, which could be considered an addition to Schacht's theory of Common-link ${ }^{12}$.

Besides, Western scholars tried to find out the dating of $I s n \bar{a} d$, which is a subject of discourse among them and Muslim scholarship as well. The following lines are the appraisal of their theories and arguments related to the dating of Isnād.

\subsection{Hadīth Criticism and Western Scholarship:}

Joseph Schacht and G. H. A. Juybnboll linked the dating of Isnād with the dating of hadith criticism and concluded that it had appeared in late years after the death of the Prophet. It might be considered a scientific approach, but they avoided the historical facts and based their premises on insufficient historical information that referred them to a conclusion which does not match with the actual historical facts. 
A thorough comparative study of their premises and historical facts reveals that it is not more than a claim that Shu 'ba b. al-Hajjajj was the first scrutiniser because hadith criticism started in the early ages of Islam after the death of the Prophet and the well-known companions like $A b \bar{u} B a k r$ (d. 13/636), ${ }^{(13)}$ Umar b. al-Khattāb (d. 23/644) $)^{(14)}$, Abdullāh b. Abbās (d. 67/687)(15) and 'Aīsha (d. 58/678)(16) criticised the Mutūnu'l-Hadith as well as transmitters, and they followed by the successor like Saīd b. Jubaīr (d. 95/714), al-Shabī (d. 100/719), Ibn Sìrīn (d. 110/728), al-Zuhrī (d. 124/742) in the scrutinising of $a h \bar{a} d \bar{t} t h^{(17)}$.

Consequently, it proved that Shu'ba was not the first scrutiniser of ahädith or transmitters as G. H. A Juynboll understood. However, the historical traditions in Juynboll's arguments could be interpreted that he was the first to scrutinise hadith transmitters in Irāq rather than in the entire Muslim world as deduced from the narration of $a l-S h \bar{a} f i{ }^{\prime} \bar{\imath}$ (d. 204/820): "If Shu 'ba had not been the ahädith were not known in Irāq". And the similar statement ascribed to Ibn Hibbān (d. 354/965 that Shu 'ba was the first to scrutinise the transmitters in Irā $q^{(18)}$.

Besides, it is notable that hadīth criticism in the early ages of first-century was not like the second half of the first century and at the beginning of the second century. In the early ages, the Companions criticised the narrators on forgetfulness, lack of attendance and late coming to the lectures of the Prophet rather than questioning

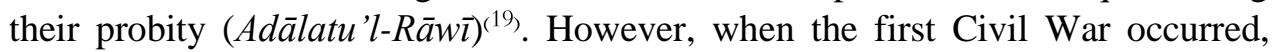
and the fabrication of hadith took place in Muslim society. Hence, Muhaddīthūn started investigating the probity of transmitters aimed to receive Ahädith from reliable and trustworthy sources.

The science of Hadīth developed with time and Muhaddithīn introduced different sciences for the preservation of Prophetic Ahāadith as well as for the differentiating the authentic from the weak and fabricated Ahädith. They compiled books in biographies and Jarha wa't-Tadīl of transmitters which considered the characteristic of this Ummah that has complete written information about those people who narrated their heritage from the early ages ${ }^{(20)}$.

\subsection{Isnād before the Second half of the First Century:}

The dating of Isnād is a subject of discourse among Orientalists, as mentioned above. J. Horovitz, Robson, and G. H. A Juynboll concluded that it was used after the first half of the first century which could be considered an early dating in Western scholarship. However, it revealed that their conclusion based on the dating of hadith criticism, while it is proved, that companions like the first two Caliphs and 'Āisha scrutinised hadiths before the second half of the first century, which is an evidence of using Isnäd at that time.

Moreover, it is an established fact that every Companion did not hear each hadith from the Prophet because they were busy in their everyday life, and it was not possible for everyone to attend every lecture of the Prophet as could be witnessed in the tradition of Anas b. Mālik (d. 90/709) ${ }^{(21)}$ and Umar b. al-Khattāb ${ }^{(22)}$.Both ahādith denote that they had mediations, but due to their reliability on each other, they usually referred to the Prophet instead of primary source. 
Despite this fact, there are lots of examples in the canonical books that many Companions referred to their sources. For instance, Abu Huraira (d. 58/678) explicitly stated that he heard the Hadith (لا تشد الرحال إلا إلى ثلاثة مساجد) from Basra b. Abī Basra al-Ghafārī,, (23) and the Hadīth about the taking-bath on Friday ( أحدكم يوم الجمعة فليغتسل from Umar b. al-Khattāb(24).

Likewise, Abdullāh b. Umar (d. 73/693), who was famous for his company with the Prophet, did not ascribe every Hadīth to him as he referred in the well-known hadith (إن الميت ليعذب ببكاء أهله عليه) to his father rather than Prophet ${ }^{(25)}$.Abdulläh $b$. $A b b \bar{a} s$ was the cousin of the Prophet and one of the jurists of companions, but he stated that he heard the Hadīth regarding the funeral prayer of Abdullāh $b$. Ubai and the Hadīth (لا تطروين كما أطرت النصارى) from Ibn al-Khattāb ${ }^{(26)}$.

Furthermore, it concluded from the follow-up of Hadīth transmission in early ages that most of the Companions followed the same methodology in mentioning their sources. They referred to them whenever someone asked them, or they considered it essential as 'Aīsha mentioned his source, Umu Salama (d. 60/680), in the hadith related to prayer after al-Asr ${ }^{27}$. As well as when $A b d u$ 'r-Rahmān conveyed the statement of 'Aīsha to Abü Huraira about his hadīth (من أدرك الفجر جنبًا فلا يصوم), he stated: he did not hear from the Prophet, but he heard from al-Fadhal b. Abbās (d. $18 / 639)^{(28)}$.

Besides, there are lots of examples in hadith collections that Ibn $A b b \bar{a} s^{(29)}, A b \bar{u}$ Saīd al-Khudrī (d. 73/693) ${ }^{(30)(31)}$ and others referred to their sources, which prove that it is a baseless claim that Isnād was not used before the Second half of the first century.

\section{Conclusion:}

The Western scholarship studied Islam and its primary sources and developed various theories about its authenticity and historical position. However, the primary purpose of their study of Prophetic hadith was to collect the historical information about the early ages of Islam that would help them in the rewriting of the Islamic history, and thus they considered the source criticism indispensable.

During the source criticism, Western scholars put in question the dating of Isnād system, and despite their difference in opinion, they called it later addition to the Ahāaìth. Leone Caetani, Aloys Sprenger, and Joseph Schacht argued that Hadīth system was not used in early ages of Islam and they dated it in the second century and onwards. While J. Horovitz, Ignaz Goldziher, Robson, and G. H. A Juynboll believe that Isnād used after the first half of the first century A. H.

The main arguments of Leone Caetani, Aloys Sprenger, is the letters of Urwa $b$. al-Zubaīr to Abdulmālik b. Marwān which are quoted al-Tabarī in his compilation. They concluded that Ibn al-Zubaìr was the oldest collecter of hadith, but he did not use Isnād and nor referred to his source except the Holy Qurān. However, it proved that it is not more than a claim because al-Tabari is not the single source for Ibn al-Zubaìr's letters. There are other earlier and authentic sources than al-Tabarī like al-Zuhrī, who quoted these letters with his chains. 
The research revealed that as the conclusion of the Leone Caetani, Aloys Sprenger, and Joseph Schacht predicated on the assumption, the conclusion of J. Horovitz, Ignaz Goldziher, Robson, and G. H. A Juynboll is far from reality as well. Because Isnād system is linked with the hadīth criticism as Joseph Schacht and G. H. A Juynboll stated in his works and concluded that it was started in the second century while considered Shu 'ba b. al-Hajjajj the first who scrutinised the transmitters. However, it is proved that hadith criticism was started in the early ages of the first century after the death of the Prophet as Abu Bakr, Umar b. alKhattāb, Abdullāh b. Abbās, and 'Aīsha scrutinised the Mutūnu'l-Hadīth as well as transmitters, and they followed by the Successor like Saīd b. Jubaīr, al-Shabī, Ibn Sìrīn, and al-Zuhrī before Shu 'ba b. al-Hajjāj.

It is concluded from a thorough review of Hadith collection that even the presence of Hadith criticism in the first half of the first century is convincing evidence of the use of Isnād at that time. Nevertheless, there are lots of examples of Companions such as Abū Huraira, 'Aīsha, Abdullāh b. Umar, Abdullāh b. Abbās, $A b \bar{u}$ Saìd al-Khudrī and others referred to their sources whenever someone asked, or they realised it essential because they did not hear each hadith from the Prophet, but due to probity and reliability on each other, they usually referred to the Prophet without mediation.

In sum-up, the dating of Isnād is a subject of discourse in Western scholarship. Most of the Western scholars based their theories on the assumption or insufficient sources and avoided historical facts. Therefore, their conclusion does not match with the authentic, established facts.

\section{(c) + This work is licensed under a Creative
Commons Attribution 4.0 International Licence.}

\section{References:}

(1) Johann Fūck, Tārīku Harakati'l-Istishrāq, Translated: Umar Lūtfī, (Leobnon: Dāru'l-Madār al-Islāmī, 1420/2000), 13.

(2) Abdu'l-Azim, al-Mūstashriqūn wa'Turāth, Hawliatu Kulyatu'sharīa wa alDirāsātu'l-Islāmia, 4/725.

(3) Ignaz Goldziher, Muslim Studies, Translated: C. R. Barber and S. M. Stern (London: George Allen \& I M W I N Ltd, 1390/1971), 2/40-47. Joseph Schacht, The Origins of Muhamadan Jurisprudence, (London: Oxford University Press, Ely House, W. 1, 1369/1950), 2-11.

(4) G. H. A Juynboll, Muslim Tradition, (Sydney: Cambridge University Press, 1403/1983), 134-159.

(5) Leone Caetani discussed this theory in his book Hawlīâtu'l-Islām as Robson cited in his article "The Isnād in Muslim Traditions" as well as M. M. Azamī in his Ph.D thesis "Dirāsāt fî̀l-Hadīth al-Nabawī wa Tārīkhi Tadwīnihi”, (Beirut, al-Maktabu'l-Islāmī, 1400/1980), 392.

(6) They would not ask about the chain (Sanad) of a narration, and when the Fitna occurred: they said name of us your men (Source), so Ahlu's-Sunnah would be regarded, and their hadith were then taken, and Ahlu'l-Bidah would be regarded, 
and their hadīth were not taken. Muslim b. al-Hajāj, Sahīh Muslim, (Beirut: Dār Ahyāu'turath al-Arabī, 1412/1991), 1/15.

(7) Schacht, The Origins of Muhamadan Jurisprudence, 36-37.

(8) Goldziher, Muslim Studies, 22. J. Shaukat, "The Isnad in Hadīth Literature", Islamic Studies, 24/4 (1405/1985), 447.

(9) J. Robson, Oriental Society Transaction, (Glasgow University, 1415/1995), "The Isnād in Muslim Traditions", XV/21. Azamī, "Dirāsāt fì'l-Hadīth al-Nabawī we Tārīkhi Tadwīnihi”, 395.

(10) Juynboll, Muslim Tradition, 20, 134, 135. G. H. A Juynboll, "The Date of Great Fitna", Arabica, XX/2 (1393/1973), 142-159.

(11) Muslim, Sahīh Muslim, 1/15.

(12) Schacht, The Origins of Muhamadan Jurisprudence, 163-175. Juynboll, Muslim Tradition, 205-217.

(13) A grandmother came to Abū Bakr as-Siddīq and asked him for her inheritance. Abū Bakr said to her, 'You have nothing in the Book of Allah, and I do not know that you have anything in the sunna of the Messenger of Allah. Go away therefore, until I have questioned the people.' (i.e.the Companions). $\mathrm{He}$ questioned the people, and al-Mūghīra $b$. Shu'ba said, 'I was present with the Messenger of Allah, when he gave the grandmother a sixth.' Abū Bakr said, 'Was there anybody else with you?' Muhammad b. Maslama al-Ansārī stood up and said the like of what al-Mūghīra said. Abū Bakr as-Siddīq gave it to her. See: Mālik, al-Mūwatā, (Beirut: Dār Ihyāi'Turāth al-Arab̄î, 1406/1986), 2/513. Abdu'r-Razzāq al-Sanaān̄̄, al-Mūsanaf, (India: al-Majlsu'l-Ilmī, 1403/1983), $10 / 274$.

(14) Abū Mūsā al-Asharī came and asked permission from Umar b. al-Khattāb to enter. He asked permission three times, and then went away Umar b. al-Khattāb sent after him and said, "What's wrong with you? Why didn't you come in?" Abū Mūsā said, "I heard the Messenger of Allah, say, 'Ask permission to enter three times. If you are given permission, then enter. If not, go away.' "Umar said, "Who can confirm this? If you do not bring me someone to confirm it, I will do such-and-such to you." Abū Mūsā went out until he came to an assembly in the mosque which was called the Majlis-al-Ansār. He said, "I told Umar b. alKhattāb that I heard the Messenger of Allah, say, 'Ask permission three times. If you are given permission, then enter. If not, go away.' Umar said, 'If you do not bring me someone who can confirm it, I will do such- and-such to you'. If any of you have heard that, let him come with me.' "They said to Abū Saīd al-Khudrī, "Go with him". Abū Saīd was the youngest of them. He went with him and told Umar b. al-Khattāb about that." Umar b. al-Khattāb said to Abū Musā, "I did not suspect you, but I feared lest people forge sayings of the Messenger of Allah. See: Mālik, al-Mūwatā, 5/1403.

(15) Misfr Azām, Maqāīs Naqd Mutūn al-Sunna, (al-Riyādh: Jāmiatu'l-Imām Muhammad b. Saud al-Islāmia, 1404/1984), 64.

(16) The dead is punished because of the lamentation of the living. Upon this 'Aīsha said: May Allah have mercy upon the father of 'Abdu'r-Rahmān (Ibn 'Umar). He did not tell a lie, but he forgot or made a mistake. The Messenger of Allah happened to pass by a (dead) Jewess who was being lamented. Upon this he said: They weep over her and she is being punished in the grave. See: Mālik, alMūwatā, 1/234. al-Bukhārī, Sahīhu'l-Bukhārī, (Beirut: Dār Tawqu'n-Najāt, 1422/2001), 2/80. Muslim, Sahīh Muslim, 2/643. 
(17) Abū Sufyān, al-Ilatu wa Ajnāsihā, (Egypt: Dāru'd-Dhīā, 1426/2005), 26-28.

(18) Jalalu'd-Din al-Suyūtī, Tabaqātu'l-Huffāz, (Beirut: Dāru'l-Kutub al-Ilmia, 1403/1983), 90. Ibn Hibbān, al-Thiqāt, (India: Dāīratu'l-Maārif, 1393/1973), $6 / 446$.

(19) Mālik, al-Mūwatā, 2/964. Muslim, Sahīh Muslim, 2/643. Abū Jafar al-Tahāwī, Sharha Mushki'l-Asār, (Beirut: Mūasisatu'r-Risāla, 1415/1994), 2/367.

(20) Mahmood Ahmad Ghāzī, Muhādharāti Hadīth, (Lahore: al-Faīsal Nāshirān , 1431/2010), 54.

(21) Anās b. Mālik narrated a hadīth from the Messenger of Allah. A man said: You heard it from the Messenger of Allah? He got very angry and said: By Allah all that we are narrating to you we did not listen from the Messenger of Allah, but we narrated from each other and did not accuse each other. See: al-Hākim, alMūstadrak, (Beirut: Dāru'l-Kutub al-Ilmia, 1411/1990), 3/365.

(22) Umar b. al-Khattāb narrated: My Ansari neighbor from Bani Umaiya b. Zaīd who used to live at `Awali al-Medīna and used to visit the Prophet by turns. He used to go one day and I another day. When I went I used to bring the news of that day regarding the Divine Inspiration and other things, and when he went, he used to do the same for me. See: al-Bukhārī, Sahīhu'l-Bukhārī, 1/29.

(23) Mālik, al-Mūwatā, 2/105. al-Humaīdī, Musnad, (Surīa: Dāru's-Saqā, 1416/1996), $2 / 181$.

(24) Abū Dawūd al-Tīāls̄ị, Musnad, (Egyp: Dār Hijar, 1409/1988), 1/56.

(25) Abū Dawūd al-Tīālsī, Musnad, 1/19.

(26) Mamar b. Rāshid, al-Jāmi, (Pakistan: al-Majls al-Ilmī, 1403/1983), 2/273. alTīālsī, Musnad, 1/29.

(27) Ahmad b. Hanbal, Musnad, (Beirut: Mūasisatu'r-Risāla, 1421/2000), 44/209256. al-Tabrānī, al-Mujmu'l-Awsat, (Egypt: Dāru'l-Haramaīn), 4/255.

(28) al-Shāfi' ‘'i, Musnad, (Beirut: Dāru'l-Kutub al-Ilmia, 1307/1890), 1/259. Muslim, Sahīh Muslim, 2/779.

(29) Ali b. al-Jad, Musnad, (Beirut: Muasisatu'n-Nādr, 1410/1989), 249.

(30) Ahmad b. Hanbal, Musnad, 17/53. Ibn Maklad, al-Ahād wa'l-Masān̄i, (alRiyādh: Dāru'r- Rāya, 1411/1990), 3/436. 